\title{
DESKRIPSI EPIDEMIOLOGI DAN PENGENDALIAN DEMAM BERDARAH DENGUE (DBD) DI KECAMATAN PURBALINGGA KABUPATEN PURBALINGGA TAHUN 2012-2016
}

\author{
Nur Zahra Priharyati ${ }^{*}$, Arif Widyanto $\left.{ }^{* *}\right)$ \\ Jurusan Kesehatan Lingkungan, Politeknik Kesehatan Kemenkes Semarang, \\ Jl.Raya Baturaden KM 12 Purwokerto, Indonesia
}

\begin{abstract}
Abstrak
Pemberantasan penyakit Demam Berdarah Dengue (DBD) selain dengan pengobatan terhadap penderita, dapat dilakukan dengan cara pengendalian vektornya. Berdasarkan laporan DKK Purbalingga kaus tertinggi DBD di Kabupaten Purbalingga adalah Kecamatan Purbalingga sebnyak 42 kasus.Tujuan penelitian ini untuk mengetahui gambaran epidemiologi dan pengendalian DBD di Kecamatan Purbalingga Kabupaten Purbalingga pada tahun 2012-2016.Jenis penelitian yang digunakan adalah deskriptif.Data disajikan dalam bentuk narasi terstruktur, grafik, dan table.Hasil penelitian menunjukkan bahwa kasus DBD pada tahun 2012 sampai tahun 2016 berdasarkan penderita yang meliputi umur dan jenis kelamin yaitu untuk umur tertinggi penderita pada usia 12 sampai dengan 25 tahun dengan jumlah 53 kasus, jenis kelamin terbanyak pada penderita DBD adalah laki-laki yaitu 273 kasus. Penyebaran kasus berdasarkan pada waktu kejadian tertinggi pada bulan Februari, dan kondisi persebaran tertinggi di kelurahan Wirasana.Tindakan pengendalian vektor DBD telah dilakukan beberapa kegiatan secara berkala dan berkelanjutan seperti survey jentik berkata, abatisasi, PSN, fogging, dan penyuluhan. Kesimpulan penelitian menunjukan kasus DBD sejak tahun 2012-2016 adalah untuk umur penderita tertinggi umur 12-25 tahun, jenis kelamin tertinggi adalah laki-laki. Penyebaran kasus tertinggi berdasar waktu tertinggi adalah bulan Februari, dan tempat dengan kasus tertinggi adalah Wirasana.tindakan pengendalian vektor yang telah dilakukan adalah Pemeriksaan Jentik Berkala, Pemberantasan Sarang Nyamuk, abatisasi, fogging, dan penyuluhan. Saran untuk ini adalah meningkatkan program PSN untuk mencegah persebaran kasus DBD.
\end{abstract}

Kata kunci:Epidemiologi; Demam Berdarah Dengue (DBD); Pengendalian vektor DBD; Kesehatan Lingkungan

\begin{abstract}
Eradication of Dengue Hemorrhagic Fever (DHF) in addition to the treatment of patients, can be done by controlling the vector. According to Purbalingga District Health Office, the highest case of DHF in Purbalingga is Purbalingga sub-district, which is 42 cases. The purpose of this research is to know the description of epidemiology and control of DHF in Purbalingga Sub-district Purbalingga Regency in 2012-2016. The type of research used is descriptive. The data are presented in the form of structured narratives, graphs, and tables. The results showed that the cases of DHF in 2012 until 2016 based on patients who include age and sex, ie for the highest age of patients at the age of 12 to 25 years with the number of 53 cases,Most of the sexes in DHF patients are male ie 273 cases. The dispersal of cases based on the time of the highest incidence was in February, and the highest dispersion condition was in Wirasana urban village. DHF vector control measures have been undertaken with several regular and ongoing activities such as regular larva surveys, abatization, Eradication of mosquito nest, fogging, and counseling. The conclusion of the study shows that DHF cases since 2012-2016 are for the highest age of aged 12-25 years and the highest sex is male. The highest case-based spread of the highest time is February, and the place with the highest case is Wirasana. Vector control measures that have been done are periodic check of mosquito larva, mosquito nest eradication, abatization, fogging, and counseling. The suggestion for this is to improve the mosquito nest eradication program to prevent the spread of DHF cases..
\end{abstract}

Keywords: Epidemiology; Dengue Hemorrhagic Fever (DHF); Control of DHF vectors; Environmental

Health. 


\section{Pendahuluan}

Rencana Pembangunan Jangka Panjang Bidang Kesehatan (RPJP-K) adalah rencana pembangunan nasional di bidang kesehatan yang merupakan penjabaran dari RPJPN Tahun 20052025, dalam bentuk dasar, visi, misi, arah dan kebutuhan sumber daya pembangunan nasional di bidang kesehatan untuk masa 20 tahun ke depan. Berbagai penyakit menular masih merupakan masalah kesehatan masyarakat.Incidence Rate penyakit Demam Berdarah Dengue (DBD) meningkat tahun demi tahun, yang disebabkan penanganan lingkungan kurang baik yang berkaitan dengan masih kurangnya perilaku hidup bersih dan sehat. (Depkes RI, 2009, h.1 dan 12)

Kasus DBD di Kabupaten Purbalingga masih banyak ditemukan, berdasarkan data Dinas Kesehatan Kabupaten Purbalingga dari tahun 20122016 masih ditemukan kasus DBD. Angka kasus DBD pada tahun 2012 terdapat 158 kasus (2 orang meninggal) dengan IR 18,03/100.000 dan CFR 1,27\%. Kasus DBD meningkat pada tahun 2013 yaitu 572 kasus (3 orang meninggal) dengan IR 64,87/100.000 dan CFR 0,52\%. Tahun 2014 mengalami penurunan tercatat 372 kasus (2 orang meninggal) dengan IR 42,05/100.000 dan CFR 0,54\%. Tahun 2015 sebanyak 245 kasus (5 orang meninggal) dengan IR 27,40/100.000 dan CFR 2,04\%. Tahun 2016 hingga pertengahan bulan November tercatat sebanyak 258 kasus (5 orang meninggal) dengan IR 2,85/10.000 dan CFR $1,94 \%$.

Wilayah Kecamatan di Kabupaten Purbalingga dengan jumlah kasus DBD tertinggi tahun 2016 adalah Kecamatan Purbalingga yaitu sebanyak 42 kasus.Berdasarkan data Dinas Kesehatan Kabupaten Purbalingga pada Kecamatan Purbalingga tahun 2012-2016 masih ditemukan kasus. Kasus DBD tercatat pada tahun 2012 sebanyak 36 kasus, kemudian naik pada tahun 2013 sebanyak 118 kasus. Angka kejadian kasus mengalami penurunan pada tahun 2014 sebanyak 53 kasus, kemudian mengalami kenaikan lagi pada tahun 2015 sebanyak 57 kasus. Pada tahun 2016 pada bulan Januari hingga pertengahan bulan November tercatat 42 kasus.

Rumusan masalah dalam penelitian ini adalah penyakit DBD yang merupakan salah satu masalahkesehatan masyarakat yang semakin luas penyebarannya sejalan dengan meningkatnya kepadatan penduduk. Penelitian ini ingin mengetahui dan mendeskripsikan bagaimanakah pendistribusian penyakit DBD berdasarkan orang, tempat, dan waktu serta upaya pengendalian vektor DBD di Kecamatan Purbalingga Kabupaten Purbalingga tahun 2012-2016.

Tujuan penelitian ini adalah untuk mendeskripsikan bagaimana pendistribusian penyakit berdasarkan orang, tempat, dan waktu serta upaya pengendalian vektor Demam Berdarah
Dengue (DBD) di Kecamatan Purbalingga Kabupaten Purbalingga tahun 2012 hingga tahun 2016.

*) npriharyati@gmail.com

**) arifwidyanto74@yahoo.com

\section{Bahan dan Metode}

Jenis penelitian yang digunakan adalah penelitian deskriptif yang bertujuan mendeskripsikan kasus dan upaya pengendalian vektor DBD di Kecamatan Purbalingga tahun 2012-2016.

Subyek penelitian ini adalah epidemiologi dan upaya pengendalian vektor DBD di Kecamatan Purbalingga Kabupaten Purbalingga tahun 20122016. Dan pengumpulan data dilakukan dengan cara wawancara dan melihat data sekunder yang diperoleh dari Dinas Kesehatan Kabupaten Purbalingga, Puskesmas Purbalingga, dan Puskesmas Bojong.

Analisis data yang digunakan adalah analisis deskriptif yang dituangkan dalam bentuk distribusi frekuensi dan disajikan dalam bentuk tabel dan naratif untuk mendeskripsikan kejadian DBD dan pengendalian vektor yang dilakukan.

\section{Hasil dan Pembahasan}

Hasil penelitian sebagai berikut :

\section{A. Gambaran Umum :}

Kecamatan Purbalingga memiliki 2 Puskesmas, yaitu Puskesmas Purbalingga dan Puskesmas Bojong. Puskesmas Purbalingga dengan wilayah kerja Bancar, Purbalingga Wetan, Purbalingga Kidul, Kandang Gampang, Purbalingga Kulon, Purbalingga Lor, Kembaran Kulon, dan Wirasana, sedangkan Puskesmas Bojong dengan wilayah kerja Bojong, Toyareja, Kedung Menjangan, Jatisaba, dan Penambongan.

Kepadatan penduduk wilayah Kecamatan Purbalingga adalah sebagai berikut dilihat berdasarkan luas daerah dan jumlah penduduk adalah sebagai berikut:

Tabel 1 : Kepadatan Penduduk di Kecamatan Purbalingga tahun 2016

\begin{tabular}{cccccccc}
\hline \multirow{2}{*}{ No } & \multirow{2}{*}{ Kelurahan } & \multicolumn{2}{c}{$\begin{array}{l}\text { Jml } \\
\text { Penduduk }\end{array}$} & \multicolumn{2}{c}{ Luas Daerah } & \multicolumn{3}{c}{$\begin{array}{c}\text { Kepadatan } \\
\text { penduduk }\end{array}$} \\
\cline { 3 - 8 } & & (Jiwa) & $(\%)$ & $(\mathrm{Ha})$ & $(\%)$ & (Jiwa/Ha) & $(\%)$ \\
\hline 1 & Bojong & 4689 & 7.7 & 146.0 & 9.9 & 32 & 5.2 \\
\hline 2 & Toyareja & 3799 & 6.3 & 175.4 & 11.9 & 22 & 3.5 \\
\hline 3 & $\begin{array}{l}\text { Kedung } \\
\text { mnjngan }\end{array}$ & 4129 & 6.8 & 125.6 & 8.5 & 33 & 5.3 \\
\hline 4 & Jatisaba & 3471 & 5.7 & 205.6 & 14.0 & 17 & 2.7 \\
\hline 5 & Bancar & 4393 & 7.2 & 109.4 & 7.4 & 40 & 6.5 \\
\hline 6 & $\begin{array}{l}\text { Purbalingga } \\
\text { Wetan }\end{array}$ & 4812 & 7.9 & 83.7 & 5.7 & 57 & 9.3 \\
\hline 7 & Penambongan & 4594 & 7.6 & 113.8 & 7.7 & 40 & 6.5 \\
\hline 8 & $\begin{array}{l}\text { Purbalingga } \\
\text { Kidul }\end{array}$ & 4621 & 7.6 & 103.2 & 7.0 & 45 & 7.2 \\
\hline 9 & $\begin{array}{l}\text { Kandang } \\
\text { Gampang }\end{array}$ & 4766 & 7.8 & 53.0 & 3.6 & 90 & 14.5 \\
\hline 10 & $\begin{array}{l}\text { Purbalingga } \\
\text { Kulon }\end{array}$ & 2800 & 4.6 & 51.9 & 3.5 & 54 & 8.7 \\
\hline
\end{tabular}




\begin{tabular}{clcccccc}
11 & $\begin{array}{l}\text { Purbalingga } \\
\text { Lor }\end{array}$ & 6098 & 10.0 & 71.8 & 4.9 & 85 & 13.7 \\
\hline 12 & $\begin{array}{l}\text { Kembaran } \\
\text { Kulon }\end{array}$ & 4841 & 8.0 & 102.3 & 6.9 & 47 & 7.6 \\
\hline 13 & Wirasana & 7722 & 12.7 & 131.5 & 8.9 & 59 & 9.5 \\
\hline & Jumlah & 60735 & 100 & $\begin{array}{c}1473 . \\
33\end{array}$ & 100 & 621 & 100 \\
\hline
\end{tabular}

Penduduk di Kecamatan Purbalingga penyebarannya tidak merata, terbukti dengan adanya jumlah penduduk yang tinggi dan rendah. Kepadatan penduduk di Kecamatan Purbalingga adalah 621 jiwa/Ha, daerah terpadat adalah Kelurahan Kandang Gampang dengan kepadatan 90 jiwa/ Ha, sedangkan daerah dengan kepadatan penduduk terendah adalah Desa Jatisaba dengan 17 jiwa/Ha.

Kepadatan penduduk di Kecamatan Purbalingga sangan dimungkinkan untuk terus meningkat tiap tahunnya karena jumlah penduduk di Kecamatan Purbalingga yang terus meningkat.

Dengan kepadatan penduduk yang tinggi berpengaruh pada persebaran penyakit demam berdarah dengue, hal ini disebabkan rumah yang saling berdekatan dan mempercepat penyebaran dan/atau penularan penyakit demam berdarah dengue mengingat jarak terbang nyamuk Aedes sp..

B. Variabel Epidemiologi DBD

1. Variabel Epidemiologi Berdasarkan Orang

a. Umur

Gambaran kasus DBD berdasarkan umur di Kecamatan Purbalingga dapat dilihat pada tabel berikut:

Tabel 2 : Kasus DBD berdasarkan variabel umur tahun 2012-2016

\begin{tabular}{ccrrrrrr}
\hline \multirow{2}{*}{ No } & \multirow{6}{*}{ Tahun } & \multicolumn{6}{c}{ Golongan Umur (Th) } \\
\cline { 3 - 8 } & & $0-5$ & $6-11$ & $12-25$ & $25-45$ & $46-65$ & $>65$ \\
\hline 1 & 2012 & 5 & 2 & 12 & 9 & 2 & 1 \\
\hline 2 & 2013 & 2 & 13 & 16 & 29 & 17 & 2 \\
\hline 3 & 2014 & 13 & 6 & 32 & 13 & 9 & 1 \\
\hline 4 & 2015 & 20 & 46 & 53 & 50 & 18 & 4 \\
\hline 5 & 2016 & 3 & 16 & 42 & 41 & 26 & 12 \\
\hline \multirow{2}{*}{ Jumlah } & 43 & 83 & 155 & 142 & 72 & 20 \\
\hline
\end{tabular}

Berdasarkan analisis golongan umur $12 \mathrm{~s} / \mathrm{d} 25$ dan 26 s/d 45 adalah golongan umur dengan kasus tertinggi pada 5 tahun terkahir. Tercatat 167 kasus untuk golongan umur 12 s/d 25, dan 130 kasus untuk golongan umur 26 s/d 45.

Pada usia tersebut sangat dimungkinkan terkena penyakit DBD karena tergolonga usia produktif. Pada umur 12-45 tahun masih kebanyakan penduduk melakukan aktivitasnya pada siang hari diluar rumah, dan nyamuk Aedes sp. melakukan aktifitas menggigit mulai pagi sampai petang dengan 2 puncak aktifitas antara pukul 09.00-10.00 dan 16.00-17.00.

\section{b. Jenis Kelamin}

Gambaran kasus DBD berdasarkan jenis kelamin di Kecamatan Purbalingga dapat dilihat pada tabelberikut :

Tabel 3 : Kasus DBD berdasarkan variabel jenis kelamin tahun 2012-2016

\begin{tabular}{|c|c|c|c|c|}
\hline \multirow[t]{2}{*}{ No } & \multirow[t]{2}{*}{ Tahun } & \multicolumn{2}{|c|}{$\begin{array}{c}\text { Jenis } \\
\text { Kelamin }\end{array}$} & \multirow[t]{2}{*}{ Jumlah } \\
\hline & & $\mathbf{L}$ & $\mathbf{P}$ & \\
\hline 1 & 2012 & 16 & 15 & 31 \\
\hline 2 & 2013 & 49 & 34 & 83 \\
\hline 3 & 2014 & 44 & 30 & 74 \\
\hline 4 & 2015 & 98 & 93 & 191 \\
\hline \multirow[t]{2}{*}{5} & 2016 & 66 & 74 & 140 \\
\hline & Jumlah & 273 & 246 & 519 \\
\hline
\end{tabular}

Tahun 2012 sampai dengan tahun 2015 penderita penyakit Demam Berdarah Dengue tertinggi adalah jenis kelamin laki-laki, sedangkan pada tahun 2016 tertinggi adalah jenis kelamin perempuan. Meski begitu jika dilihat sejak tahun 2012 sampai dengan tahun 2016 tercatat kasus DBD tertinggi pada jenis kelamin laki-laki dengan jumlah penderita sebanyak 273 kasus sedangkan perempuan dengan jumlah penderita sebanyak 246 kasus.

Hal tersebut dapat disebabkan karena lakilaki lebih banyak bekerja diluar ruangan sehingga sangat dimungkinkan tergigit nyamuk Aedes sp. , selain itu pendatang banyak yang berjenis kelamin laki-laki

\section{Variabel Epidemiologi Berdasarkan \\ Waktu}

Gambaran kasus DBD berdasarkan variabel waktu di Kecamatan Purbalingga dibagi menjadi 2 yaitu bulan kejadian tan tahun dapat dilihat pada sebagai berikut :

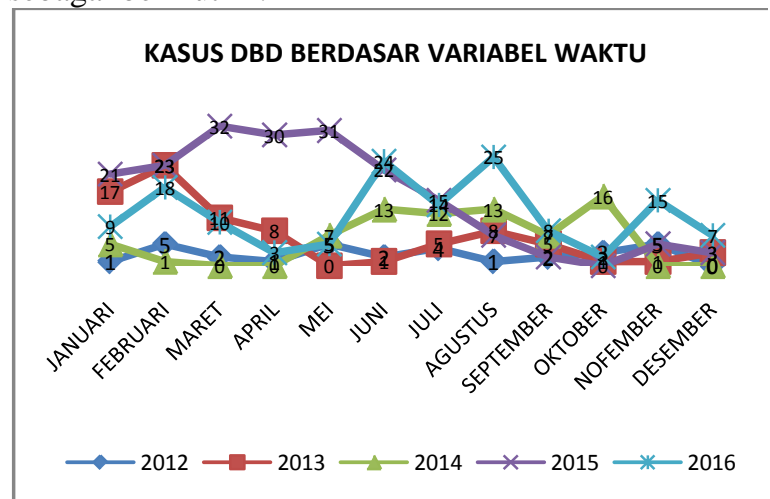

Gambar 1 : Penderita DBD berdsarkan waktu kejadian

Bulan kejadian terendah penyakit demam berdarah dengue dari tahun 2012 sampai dengan 2016 adalah bulan September, Oktober, Nofember, dan Desember. Sedangkan bulan tertinggi untuk kejadian demam berdarah dengue adalah bulan Februari sejak tahun 2012 hingga tahun 2016 tercatat 70 kasus. Hal tersebut bisa saja terjadi 
karena Februari masih termasuk musim hujan sehingga banyak genangan air diluar rumah dan memungkinkan sekali nyamuk aedes $s p$. berkembang biak di tempat-tempat yang tergenang air.

Untuk mengurangi penyebaran penyakit demam berdarah dengue dapat dilakukan dengan upaya pengendalian seperti kegiatan pemberantasan sarang nyamuk (PSN) dan masyarakat dapat berperan aktif dalam pelaksaannya. Di Kecamatan Purbalingga sendiri khususnya wilayah kerja Puskesmas Purbalingga, kesadaran masyarakat akan PSN masih kurang sehingga dari pada dua tahun terakhir jumlah penderita meningkat.

\section{Variabel Epidemiologi Berdasarkan \\ Tempat \\ Gambaran kasus DBD berdasarkan} tempat atau menurut asal desa/kelurahan asal penderita, adalah sebagai berikut:

\begin{tabular}{|c|c|c|c|c|c|c|c|c|c|}
\hline \multirow{2}{*}{ No } & \multirow{2}{*}{ KELURAHAN } & \multicolumn{5}{|c|}{ TAHUN } & \multirow{2}{*}{$\underset{\mathrm{L}}{\mathrm{JM}}$} & \multirow{2}{*}{$\begin{array}{c}\text { JML } \\
\text { PDD } \\
K \\
2016\end{array}$} & \multirow{2}{*}{$\begin{array}{c}\text { IR } \\
201 \\
6\end{array}$} \\
\hline & & 2012 & 2013 & 2014 & 2015 & 2016 & & & \\
\hline 1 & BANCAR & 1 & 11 & 2 & 14 & 7 & 35 & 4393 & 1.59 \\
\hline 2 & $\begin{array}{l}\text { PURBALIINGGA } \\
\text { WETAN }\end{array}$ & 5 & 12 & 16 & 25 & 22 & 80 & 4812 & 4.57 \\
\hline 3 & $\begin{array}{l}\text { PURBALINGGA } \\
\text { KIDUL }\end{array}$ & 5 & 14 & 11 & 18 & 9 & 57 & 4621 & 1.95 \\
\hline 4 & $\begin{array}{l}\text { KANDANG } \\
\text { GAMPANG }\end{array}$ & 6 & 9 & 12 & 19 & 6 & 52 & 4766 & 1.26 \\
\hline 5 & $\begin{array}{l}\text { PURBALINGGA } \\
\text { KULON }\end{array}$ & 2 & 5 & 5 & 12 & 19 & 43 & 2800 & 6.79 \\
\hline 6 & $\begin{array}{l}\text { PURBALINGGA } \\
\text { LOR }\end{array}$ & 4 & 10 & 5 & 16 & 13 & 48 & 6098 & 2.13 \\
\hline 7 & $\begin{array}{l}\text { KEMBARAN } \\
\text { KULON }\end{array}$ & 8 & 5 & 10 & 9 & 8 & 40 & 4841 & 165 \\
\hline 8 & $\begin{array}{l}\text { KLLNA } \\
\text { WIRASANA }\end{array}$ & $\frac{8}{0}$ & $\frac{3}{17}$ & $\frac{10}{12}$ & $\frac{9}{47}$ & $\frac{8}{9}$ & $\frac{40}{85}$ & 7722 & $\frac{1.65}{1.17}$ \\
\hline 9 & PENAMBONGAN & 0 & 0 & 0 & 8 & 6 & 14 & 4599 & 1.30 \\
\hline 10 & BOJONG & 0 & 0 & 1 & 9 & 11 & 21 & 4689 & 2.35 \\
\hline & TOYAREJA & 0 & 0 & 0 & 3 & 30 & 33 & 3799 & 7.90 \\
\hline 13 & $\begin{array}{l}\text { KEDUNGMENJANG } \\
\text { AN }\end{array}$ & 0 & 0 & 0 & 4 & 0 & 4 & 4129 & 0 \\
\hline 14 & JATISABA & 0 & 0 & 0 & 7 & 0 & 7 & 3471 & 0 \\
\hline & JUMLAH & 31 & 83 & 74 & 191 & 140 & 519 & 60770 & \\
\hline
\end{tabular}

Hasil analisis distribusi kasus menurut tempat selama 5 tahun bervariasi. Kelurahan yang paling banyak terkena penyakit demam berdarah dengue adalah Kelurahan Wirasana dengan jumlah keseluruhan sejak tahun 2012 hingga 2016 adalah 85 kasus. Kelurahan tersebut merupakan daerah padat penduduk dengan kepadatan penduduk mencapai 59 jiwa/Ha dan termasuk daerah perkotaan. Selain Kelurahan Wirasana ada juga Kelurahan Purbalingga Wetan yang daerahnya padat penduduk mencapai 57 jiwa/Ha dan dengan jumlah kasus terbanyak kedua sebanyak 25 kasus pada tahun 2012 sampai dengan 2016, selain itu Kelurahan Purbalingga wetan merupakan daerah yang dekat dengan jalan raya.

\section{Program Pengendalian Demam Berdarah Dengue (DBD) Kecamatan Purbalingga}

Wilayah Kecamatan Purbalingga diketahui memiliki dua puskesmas yaitu Puskesmas Purbalingga dan Puskesmas Bojong.Pada ke dua puskesmas tersebut telah melakukan beberapa pengendalian seperti Pemberantasan Sarang Nyamuk, Pemeriksaan Jentik Berkala (Survey jentik), Abatisasi, Fogging, dan Penyuluhan.Hasil dari pengendalian tersebut dapat dilihat pada tabel berikut :
Table 4 : Tabel pengendalian DBD di Kecamatan Purbalingga tahun 2016

\begin{tabular}{|c|c|c|c|c|c|c|}
\hline \multirow{2}{*}{ No } & \multirow{2}{*}{ Kelurahan } & \multicolumn{5}{|c|}{ Pengendalian Yang Dilakukan } \\
\hline & & Pjb & Psn & Abatisasi & Fogging & Penyuluhan \\
\hline 1 & Bancar & $\mathrm{V}$ & $\mathrm{V}$ & - & - & $\mathrm{V}$ \\
\hline 2 & $\begin{array}{l}\text { Purbalingga } \\
\text { Wetan }\end{array}$ & $\mathrm{V}$ & $\mathrm{V}$ & - & $\mathrm{V}$ & $\mathrm{V}$ \\
\hline 3 & $\begin{array}{l}\text { Purbalingga } \\
\text { Kidul }\end{array}$ & $\mathrm{V}$ & $\mathrm{V}$ & - & - & V \\
\hline 4 & $\begin{array}{l}\text { Kandang } \\
\text { Gampang }\end{array}$ & $\mathrm{V}$ & $\mathrm{V}$ & - & - & $\mathrm{V}$ \\
\hline 5 & $\begin{array}{l}\text { Purbalingga } \\
\text { Kulon }\end{array}$ & $\mathrm{V}$ & $\mathrm{V}$ & - & - & $\mathrm{V}$ \\
\hline 6 & $\begin{array}{l}\text { Purbalingga } \\
\text { Lor }\end{array}$ & $\mathrm{V}$ & $\mathrm{V}$ & - & V (2) & $\mathrm{V}$ \\
\hline 7 & $\begin{array}{l}\text { Kembaran } \\
\text { Kulon }\end{array}$ & $\mathrm{V}$ & $\mathrm{V}$ & - & - & $\mathrm{V}$ \\
\hline 8 & Wirasana & $\mathrm{V}$ & $\mathrm{V}$ & - & - & $\mathrm{V}$ \\
\hline 9 & Bojong & $\mathrm{V}$ & $\mathrm{V}$ & $\mathrm{V}$ & - & $\mathrm{V}$ \\
\hline 10 & Toyareja & $\mathrm{V}$ & $\mathrm{V}$ & $\mathrm{V}$ & $\mathrm{V}(2)$ & $\mathrm{V}$ \\
\hline 11 & $\begin{array}{l}\text { Kedung } \\
\text { Menjangan }\end{array}$ & $\mathrm{V}$ & $\mathrm{V}$ & $\mathrm{V}$ & - & $\mathrm{V}$ \\
\hline 12 & Jatisaba & $\mathrm{V}$ & $\mathrm{V}$ & $\mathrm{V}$ & - & $\mathrm{V}$ \\
\hline 13 & Penambongan & $\mathrm{V}$ & $\mathrm{V}$ & $\mathrm{V}$ & - & $\mathrm{V}$ \\
\hline
\end{tabular}

1. Pemeriksaan Jentik Berkala (PJB)

Berdasarkan tabel 4 kegiatan survey jentik telah dilakukan oleh seluruh kelurahan dan/atau desa di wilayah kerja Puskesmas Purbalingga dan Puskesmas Bojong.Kegiatan tersebut dilakukan oleh petugas puskesmas dengan jumlah tenaganya 3 orang untuk petugas Puskesmas Purbalingga dan 2 orang petugas pada Puskesmas Bojong.

Metode yang digunakan pada survey jentik di Puskesmas Bojong dan Puskesmas Purbalingga adalah metode visual, yaitu dengan hanya melihat ada atau tidaknya jentik di setiap genangan air tanpa mengambil jentiknya.Alat dan bahan yang digunakan adalah senter dan alat tulis.

Survey jentik biasanya dilakukan bersamaan dengan kegiatan pemberantasan sarang nyamuk (PSN).Selain itu kecamatan Purbalingga juga telah melaksanakan program juru pemantau jentik (Jumantik) yang wajib ada pada setiap rumah yang ada di Kecamatan Purbalingga.

2. Pemberantasan Sarang Nyamuk

Pemberantasan Sarang Nyamuk (PSN) melalui peran serta masyarakat dengan kegiatan 3M Plus yaitu menguras tempat-tempat penampungan air, menutup rapat tempat penampungan air, mengumpulkan, mengubur, dan/atau memanfaatkan atau menyingkirkan barang-barang bekas yang dapat menampung air hujan. Selain itu ditambah dengan mengganti air vas bunga, minuman burung, memperbaiki talang air yang tidak lancar, menutup lubang-lubang pada potongan bambu atau pohon.

Pada pelaksanannya Puskesmas Purbalingga dan Puskesmas Bojong berbeda penerapannya.Puskesmas Purbalingga melaksanakan PSN dengan periode waktu 1 bulan 
sekali oleh petugas puskesmas dengan jumlah 3 orang petugas. Berbeda dengan Puskesmas Bojong, pelaksaan PSN dilakukan pada 1 minggu sekali untuk masyarakat wilayah kerja dan 3 minggu sekali dengan bantuan dari petugas puskesmas sebanyak 2 orang.

Meskipun begitu telah di anjurkan melaksanakan kegiatan PSN 1 minggu sekali di Kecamatan Purbalingga tetap saja belum terlaksana karena kesadaran masyarakat belum ada selain itu Kecamatan Purbalingga merupakan wilayah perkotaan sehingga masyarakat banyak yang sibuk bekerja dan tidak sempat melakukan PSN dirumah masing-masing. Hal tersebut menjadi pemicu tingginya kasus demam berdarah dengue di wilayah Kecamatan Purbalingga.

\section{Abatisasi}

Pada tabel 4 abatisasi hanya dilakukan di wilayah kerja Puskesmas Bojong saja, abatisasi dilakukan apabila ada petugas kader yang meminta bubuk abate pada pihak puskesmas. Kegiatan penaburan abate dilakukan oleh kader tiap Kelurahan atau Desa dengan panduan yang telah diberikan oleh petugas puskesmas.

Penaburan abate dilakukan pada rumah yang memiliki bak mandi permanen dan ditemukan jentik nyamuk dalam bak mandi tersebut. Abate yang diberikan dalam bentuk sachet yang berisi 1 gram/sachet. Bubuk abate tersebut dapat dituangkan pada bak mandi permanent atau pada tempat penampungan air dengan perbandingan 1 gram per 10 liter air. Dan apabila dilakukan sesuai SOP dengan menusuk-nusuk bubuk abate terlebih dahulu dan langsung diletakkan pada wadah penampungan air atau tempat-tempat yang sulit dikuras didaerah yang sulit air.

Wilayah kerja Puskesmas Purbalingga sendiri belum menerapkan dan/atau tidak menganjurkan penggunaan bubuk abate pada masyarakat di wilayah kerjanya, hal tersebut memungkinkan menjadi penyebab perbedaan banyaknya kasus demam berdarah dengue antara wilayah kerja Puskesmas Purbalingga dan Puskesamas Bojong yang begitu jauh.

\section{Fogging}

Pengendalian vektor di wilayah kerja Puskesmas Purbalingga dan Puskesmas Bojong dengan cara fogging dilakukan dengan beberapa prosedur seperti apabila terjadi peningkatan kasus demam berdarah dengue atau ditemukan kasus demam berdarah dengue dalam wilayah yang berdekatan lebih dari 2 kasus dan/atau terjadi kematian akibat kasus DBD.

Apabila hal tersebut diatas terjadi maka akan dilakukan penyelidikan epidemiologi (PE) oleh petugas puskesmas setempat dan petugas dari Dinas Kesehatan Kabupaten Purbalingga. Kegiatan PE dilakukan bersama dengan kegiatan PSN dan survey jentik di daerah sekitar kasus, apabila hasil dari PE menunjukan hasil perhitungan $\mathrm{HI}$ lebih dari
5\% (>5\%) maka dimungkinkan akan terjadinya penyebarluasan DBD di lokasi tersebut. Setelah seluruh prosedur dilakukan maka langkah selanjutnya adalah dilakukan pengendalian dengan cara pengasapan atau fogging.

Metode pelaksanaan dengan cara fogging termal insektisida yang dicampur dengan solar dengan bahan bakar pertalite dengan titik nyala tinggi, disebarkan dengan diinjeksikan kedalam aliran gas panas berkecepatan tinggi yaitu dengan alat mesin fogging (swing fog). Sedangkan insektisida yang digunakan dalam fogging adalah piretrin.

Daerah yang dilakukan fogging adalah diwilayah penderita kurang lebih satu komplek atau 1 RT yang terdiri dari fasilitas umum, perumahan penduduk, sekolah, pekarangan, kebun, dan halaman. Tenaga pelaksana sebanyak 12 orang dari DKK Purbalingga yang terdiri dari 6 orang operator fogging, 4 orang pengawas, 1 orang supervisor, 1 orang entomologist, dan didampingi petugas kesehatan setempat, serta beberapa perangkat desa.

Peralatan yang digunakan yaitu mesin fogging, pakaian kerja, sarung tangan, peralatan (jrigen, gelas ukur, corong, toolkit), helmet, masker, kendaraan khusus, kacamata safety, dan air plug.Bahan yang digunakan adalah insektisida, solar, dan bensin pertalite.

5. Penyuluhan

Penyuluhan dilakukan menggunakan metode audio visual yaitu menggunakan LCD dan bahan presentasi.Penyuluhan mengenai pemberantasan sarang nyamuk (PSN), dan bahaya penyakit demam berdarah dengue.Berdasar tabel 4.4 penyuluhan dilakukan di semua wilayah kerja Puskesmas Purbalingga dan Puskesmas Bojong.

Puskesmas Purbalingga dan Puskesmas Bojong memiliki waktu yang berbeda dalam pelaksaan penyuluhan. Puskesmas Purbalingga melakukan penyuluhan dengan periode 1 bulan sekali pada setiap kelurahan dan pada waktu sebelum fogging. Penyuluhan dilakukan bersama dengan petugas dari Kelurahan/Desa setempat.Adapun periode lanjutan yaitu 3 kali dalam satu tahun.Petugas yang melaksanakan kegiatan penyuluhan dari puskesmas adalah 2 atau 3 orang.

Puskesmas Bojong melakukan penyuluhan pada pertemuan rutin atau mingguan yang dilakukan di kelurahan atau desa di wilayah kerja puskesmas Bojong.Penyuluhan dilakukan oleh 2 atau 3 orang petugas dari puskesmas Bojong.

\section{Kesimpulan}

Berdasarkan uraian hasil dan pembahasan, maka penulis dapat mengambil kesimpulan sebagai berikut :

1. Penyebaran penyakit demam berdarah dengue (DBD) di Kecamatan Purbalingga berdasarkan variabel orang dengan golongan 
umur tertinggi sejak tahun 2012-2016 adalah golongan umur remaja yaitu 12-25 tahun. Penyebaran penyakit DBD berdasarkan variabel orang golongan jenis kelamin tertinggi sejak tahun 2012-2016 adalah lakilaki.

2. Kasus demam berdarah dengue (DBD) yang terjadi di Kecamatan Purbalingga berdasarkan variabel waktu tertinggi sejak tahun 20122016 adalah pada bulan Februari.

3. Kasus demam berdarah dengue (DBD) yang terjadi di Kecamatan Purbalingga berdasar tempat tertinggi pada tahun 2012-2016 adalah di Kelurahan Wirasana.

4. Di Kecamatan Purbalingga yaitu wilayah kerja Puskesmas Purbalingga dan Puskesmas Bojong telah melakukan beberapa pengendalian Demam Berdarah Dengue (DBD) seperti Pemeriksaan Jentik Berkala, Kegiatan Pemberantasan Sarang Nyamuk (PSN), kegiatan abatisasi, kegiatan fogging, dan penyuluhan. Survey jentik dan kegiatan Pemberantasan Sarang Nyamuk (PSN) dilaukan oleh seluruh masyarakat Kecamatan Purbalingga sesuai program yang berlaku di Puskesmas Purbalingga dan Puskesmas Bojong. Abatisasi hanya dilakukan di daerah wilayah kerja Puskesmas Bojong. Kegiatan fogging dilaksanakan setelah terjadinya kenaikan kasus atau telah terjadi kasus di satu wilayah lebih dari $2(>2)$ dan/atau telah terjadi kematian akibat kasus demam berdarah dengue. Sedangkan kegiatan penyuluhan dilakukan diseluruh wilayah Kecamatan Purbalingga oleh petugas Puskesmas pada saat melakaukan fogging dan pertemuan kader.

\section{Daftar Pustaka}

ChasanS,Kusnadi.2006.PengendalianVektordanBin atangPengganggu(VektorControlManual). Makasar:PoltekkesKesehatan Lingkungan Makasar

DepartemenKesehatanR.I.DirektoratJendralPengen dalianPenyakitDan

PenyehatanLingkungan(DIT.JEN.PP\&PL), 2001,PedomanEkologi Dan AspekPerilaku Vektor,Jakarta:DIT.JEN.PP\&PL.

Departemen Kesehatan R.I. Direktorat Jendral PPM \& PLP, 1986, Demam Berdarah Dengue Epidemiologi dan Pemberantasan Di Indonesia, Jakarta : DIT.JEN.PPM\&PLP.

Dinas Kesehatan Kabupaten Purbalingga, 2012, Laporan Kasus Demam Berdarah Dengue Tahun 2012, Purbalingga : Dinas Kesehatan Kabupaten Purbalingga

), 2013, Laporan Kasus Demam Berdarah Dengue Tahun 2013, Purbalingga : Dinas Kesehatan Kabupaten Purbalingga
), 2014,

Laporan Kasus Demam Berdarah Dengue Tahun 2014, Purbalingga : Dinas Kesehatan Kabupaten Purbalingga

), 2015,

Laporan Kasus Demam Berdarah Dengue Tahun 2015, Purbalingga : Dinas Kesehatan Kabupaten Purbalingga.

), 2016,

Laporan Kasus Demam Berdarah Dengue Tahun 2016, Purbalingga : Dinas Kesehatan Kabupaten Purbalingga.

Dirjen PPM dan PLP, 1992, Petunjuk Teknis Pemberantasan Nyamuk Penularan Penyakit Demam Berdarah Dengue, Jakarta : Depkes RI

Ditjen PP dan PL Depkes RI, 2008, Modul Pelatihan Bagi Pelatih Pemberantasan Sarang Nyamuk (PSN) DBD Dengan Pendekatan Komunikasi Perubahan Perilaku/KPP (Communications for Behavioral Impact/Combi).Jakarta : DIT.JEN.PP\&PL

Isnaeni, PF. 2013.Studi Pengendalian Vektor Demam Berdarah Dengue (DBD) Di Wilayah Perimeter dan Buffer Pelabuhan Tanjung Intan Kantor Kesehatan Pelabuhan (KKP) Kelas II Cilacap Tahun 2012.Purwokerto : Jurusan Kesehatan Lingkungan Poltekkes Kemenkes Semarang.

Istiqomah Nur. 2006.Studi Deskriptif Kasus Demam Berdarah Dengue (DBD) Di Kecamatan Purwokerto Utara Tahun 2006. Purwokerto : Jurusan Kesehatan Lingkungan Poltekkes Kemenkes Semarang.

Kementerian Kesehatan RI Ditjen PP\&PL Dit.PPBB.2012.Petunjuk Teknis Pemberantasan Sarang Nyamuk oleh Jumantik.Jakarta : DIT.JEN.PP\&PL.

Pramurditya Ratna. 2014.Deskripsi Pelaksanaan Pemberantasan SArang Nyamuk (PSN) Demam Berdarah Dengue (DBD) Di Kelurahan Karangpucung Kecamatan Purwokerto Selatan Kabupaten Banyumas Tahun 2014 . Purwokerto : Jurusan Kesehatan Lingkungan Poltekkes Kemenkes Semarang.

Badan Pusat Statistik Kabupaten Purbalingga. 2016. Statistik Daerah Kecamatan Purbalingga 2016. Purbalingga : BPS Kabupaten Purbalingga.

Utari, P. 2012. Deskriptif Demam Berdarah Dengue Berdasarkan Variabel Epidemiologi di Wilayah Puskesmas I Wangon Kabupaten Banyumas Tahun 2011.Purwokerto : Jurusan Kesehatan Lingkungan Poltekkes Kemenkes Semarang. 

amberdarah1.html, (diakses 23 Desember 